\title{
MULTICULTURAL HERITAGE OF THE MEMORY OF LOWER SILESIA. A STUDY OF SELECTED SITES OF MEMORY
}

Violetta JULKOWSKA

\section{ABSTRACT}

The topic of text is the problem of Prussian cultural heritage of Lower Silesia, seen from two different perspectives. First, the historical moment of this heritage appearing is introduced and second, the way of its contemporary presence and connected cultiural problems. As a key study were discussed from both perspectives: evangelical church in Karpacz so-called Wang Temple (brought in first half of XIX-th century by Prussian king Wilhelm III from Norway) - nowadays under protection of polish evangelical parish; also: life and charity work of Marianna Orańska owner of the castle in Kamieniec Ząbkowicki and neighbourhood grounds - nowadays touristic route leading on the borderland of Poland and Czech Republic, following in Marianna's steps and history of evangelical community from Tyrol, brought to Mysłakowice by Prussian king Wilhelm III - nowadays Tyrol's House lead by Zierthall commune from Austria.

\section{KEYWORDS:}




\section{HISTORICAL COMPLEXITY OF THE STUDIES INTO THE 19TH-CENTURY HERITAGE OF MEMORY OF LOWER SILESIA}

Lower Silesia is a region unusually saturated with objects of multicultural heritage, making it stand out among the historical regions of Central Europe. This relatively small area had a turbulent past, while the location at the intersection of major European routes, the fame of natural resources, and good farming conditions attracted several waves of settlement. Since the local community has consisted of various ethnic and cultural groups for centuries, the heritage of memory related to this area is a fascinating research problem. 'The cultural complexity of this heritage is still being explored in its many facets, and the conclusions concerning individual objects and places rarely provide grounds for generalisations about the whole studied area.

The Lower Silesian heritage of memory was a difficult subject and seldom raised, for political reasons, for many years following the war. It was quite unambiguously associated with more than two hundred years of political and economic presence of first the Prussian state, then the German, in the Silesia, and with the forced displacement of the German population from this region that took place after World War II, in the spring and summer of 1946. Due to the political decisions made by the post-war communist regime, there were many dramatic turns to the fates of this heritage. One cannot understand that situation without taking into account the complex process of the formation of a new cultural identity and historical awareness of the settlers who arrived at Lower Silesia after World War II. The currently observed change in the attitude of local communities towards the cultural heritage, which is being treated as a heritage of memory, results from a long historical process, the scope of which gradually included subsequent generations of post-war residents. In the long run, their attitude towards the heritage of memory was contingent on the changing political and ideological situation, which affected the ways this heritage was regarded and treated. The change in the mentality of the inhabitants of Lower Silesia is not insignificant either, since their third and fourth post-war generations decide now on how to protect and include in the heritage of memory that which the two preceding generations considered as foreign. The arbitrary and discriminatory division of the cultural herigage into "domestic" and "foreign" was made by the communist authorities. It was purposeful, done for ideological and propaganda reasons, to serve an important social role. By creating the myth of the Recovered Territories, the communist authorities

${ }^{1}$ Cf. Błogostawiony kraj? Szkice o historii i pamięci Dolnego Ślaska [Blessed land? Essays on the history and memory of Lower Silesia], ed. D. Mrgiela, K. Ruchniewicz, Wrocław 2011; Śląsk. Rzeczywistości wyobrażone [Silesia: Imagined realities], ed. W. Kunicki, with the assistance of N. \& K. Żarski, Poznań 2009, p. 7-76. 
projected the idea of nation and state on the middle ages, so that the new settlers felt they were returning to a Polish territory. The idea was based on an ahistorical notion of an ethnically homogeneous national state under the Piast dynasty, whose Western territories were supposedly seized by the Germans and Germanised. Thanks to this timeless structure of the myth, the communist authorities could arbitrarily present and interpret the historical events which had developed within a precise timeframe. In their interpretation of restoring Silesia to the Motherland, the communists ignored important historical, social, and economic processes taking place in this area since the 14th centrury. ${ }^{2}$ The myth of Recovered Territories, prpetuated by the communist propaganda and maintained in the official historical education, strongly affected the historical awareness of the Polish society for many years after the war. The difficult situation of the post-war inhabitants of Lower Silesia, which can be construed as a peculiar state of political and social suspension, resulted from the sense of uncertainty of their situation due to the complete severance of their cultural continuity and the prolonged lack of actual legal regulations. Under the law, the settlers were not owners but perpetual leaseholders of the post-German immovable and movable property they held. The new inhabitants witnessed, on the one hand, the struggle of the authorities with the so-called "looters" plague and the demolition or destruction of historic "post-German" objects, which were treated as stores of valuable building materials during the post-war reconstruction of the country on the other. In the communist regime propaganda, the perception of the Prussian and German heritage in particular was distinctly negative as belonging to the "traditional enemy". For this reason they suffered the fate of the spoils of war or, even more often, the slow decay and oblivion.

The last decade, associated with the European political context, brings about a new situation in which the question to whom the cultural heritage belongs and who is responsible for it can disregard the previous ideological conditions which had become obsolete at the turn of the 1990s. They were replaced by bilateral and international, political and legal regulations, some of which directly relate to the obligation to protect the monuments and cultural heritage. On the other hand, both local and international cultural, social, and economic initiatives, associated with the responsibilities of local authorities as the present-day keepers of the area, largely relate to the cultural heritage as a kind of an asset. It reflects a new phase of the formation and maturation of historical awareness, reaching the stage when the local community

${ }^{2}$ Cf. G. Briesewitz, "Ludzie odzyskani? Polonia wrocławska - pomiędzy mitem a historią" [Recovered people? The Polish diaspora in Wroclaw - between myth and history], in Cf. Btogosławiony kraj? Szkice o historii i pamięci Dolnego Ślaska [Blessed land? Essays on the history and memory of Lower Silesia], ed. D. Margiela, K. Ruchniewicz, Wrocław 2011, p. 107-109. 
realises that the memory of a cultural heritage is a permanent and non-opportunistic cultural obligation, which imposes the task of protecting and commemorating the cultural heritage on every local community, regardsess on its emotional relation to this heritage. The question to what extent and in what circumstances such an ideal state of cultural awareness of heritage protection can be achieved is being studied by culture historians.

\section{JUSTIFICATION FOR THE CHOICE OF RESEARCH SUBJECT AND OBJECTS FOR ANALYSIS}

Lower Silesia as the proper name of the western part of the Province of Silesia is related to the choice of the geographical and cultural area of research and its chronological limits. The objects constituting the Lower Silesian heritage of memory were selected from within this framework. What should be explained first is the name of the province, which is more recent than the history of many Silesian towns and villages in this historical area. It appeared for the first time around the 16th century to indicate the lands situated between the Sudety, Lusatia, and Greater Poland, intersected by the broad valley of the Oder. ${ }^{3}$ The name emerged when these lands were formally ruled by the Habsburgs. It was only due to the political events related to the Silesian Wars and the competition with Austria which the Prussia won in 1742 that made the name of the Lower SIlesian Province appear in historiography and cartography at the turn of the 19th century. It was seen as synonymous with the Prussian holdings in Silesia.

The studied subject consists of selected examples of the Lower Silesian heritage, originating in the first half of the 19th Century. The peculiar nature of this heritage is such that while it belongs to the Prussian heritage, a more detailed analysis reveals its more complicated cultural situation. For many years after World War II, the clear association between the discussed objects and the Prussian cultural heritage made carrying out any reliable historical and cultural research into them impossible. The present-day studies on the heritage of the 19th-century culture of Lower Silesia take into account the methodological and historical specificity of the regional studies of Silesia. ${ }^{4}$ This study analyses three selected facets included in the difficult heritage of

Cf. Teresa Kulak, "Dolny Śląsk w latach 1815-1870” [Lower Silesia in 1815-1870], inDolny Śląsk. Monografia historyczna [Lower Silesia: A historical monograph], ed. W. Wrzesiński, Wrocław 2009, p. 393 ff.

${ }^{4}$ S. Bednarek, "Regionalizm dolnośląski - teraźniejszość i przyszłość” [Lower Silesian regionalism - present and future], in Regionalizm polski u progu XXI wieku [Polish regionalism at the turn of the 21 st century], ed. S. Bednarek, Wrocław 1994, p. 67. 
memory of Lower Silesia, namely the Vang stave church in Karpacz Górny, the palace of Princess Marianne of Orange in Kamieniec Ząbkowicki, and the houses of Tyrolean emigrants in Mysłakowice.

My search for examples focused on the object which could show the workings of the memory of heritage, as well as the modern rituals of memory and the attitudes towards this heritage shown by subsequent generations, institutions, and responsible entities. The aim of this exploration was to present the history of particular objects since their creation, as well as the people and ideas related to them. The identification of the network of relations between the objects and their cultural environment was an additional aspect of the research. The presented conclusions, from field studies as well, concern the functioning of the historical memory and the exploration of the present-day role the heritage of memory fulfils on the local projects carried out in the recent years by the local authorities and inhabitants.

The research was inspired by the French and German literature on memory studies and included such heritage of memory components as events, people, objects, histories, and phenomena, in line with Pierre Nora's general idea of "sites of memory" developed by German scholars. ${ }^{5}$ Moreover, the selected examples enabled the observation of both the old and modern awareness of cultural heritage. In view of the above aims and assumptions, the research subject was defined as follows in relation to the chosen objects of the heritage of memory:

- The memory of the heritage of Tyrolean Protestants from the times of religious emigration in the middle 19th century and the modern forms of commemorating the cultural heritage of the Tyroleans, in particular their specific wooden architecture.

- The Norwegian cultural heritage in the form of the wooden architecture of the Vang stave church in Karpacz Górny as a sign of the awareness of heritage conservation, emergent in the middle 19th century, and the first actions taken in this matter, as well as the modern forms of referring to the heritage of memory by the Lutheran Church community in Karpacz.

- The memory of the activities of Marianne of Orange in the Kłodzko Vally and Kamieniec Ząbkowicki, illustrated by a transfrontier Polish-Czech cultural and tourism project.

${ }^{5}$ Cf. B. Szacka, Czas przeszły, pamięć i mit [Past tense, memory, and myth], Warszawa 2006; Pamięć zbiorowa $i$ kulturowa. Wspótczesna perspektywa niemiecka wobec pamięci [Collective and cultural memory: The modern German outlook on memory], ed. M. Saryusz-Wolska, Kraków 2009. 


\section{THE HERITAGE OF THE PRUSSIAN TIMES IN THE LOWER SILESIAN CULTURAL LANDSCAPE}

Travelling across Lower Silesia, we may notice its landscape diversity. It is a fairly vast land, stretching to the south along the mountain ranges of Sudety and Karkonosze, from the Moravian Gate to the east, through mountain passes and valleys to the west, towards the western reaches of the Jizera Mountains, where the mountains become the highland landscape of Upper Lusatia. The mountain ranges form the natural southern boundary of Lower Silesia, yet its peculiar topography opens the land to the south through accessible passes and river valleys. The natural depressions were known and used as trails and trade routes leading to the Czech Moravia. Whereas the valleys of the rivers originating in the southern part of the Karkonosze (e.g., Elbe, Jizera) opened the land to the Western Europe. The exploitation of the Sudety continued since the middle ages thanks to the excavations of gold and silver, metal ores, as well as valuable mineral resources, which were being mined by the Walloons. In the foothils of the Sudetes, there is a fertile plateau stretching from Głogów to Brzeg and the Nysa River, where various population groups from the South and West settled since the 12th century. ${ }^{6}$ In the times of the Piasts, it was the area where the first towns and villages were founded upon the German law. The spatial arrangement of these foundations, still recognisable in the cultural landscape, count among the oldest such witnesses on Polish soil. For many centuries, the natural northern and north-western boundary of the region was the marshy valleys of the Oder and its numerous tributaries, such as the Barycz Valley, separating Silesia from Greater Poland. To the north of Wrocław, from the height of the Trzebnickie Hills, a wide panorama of Lower Silesian woodlands can be seen stretching along the line of towns: Kluczbork, Namysłów, Brzeg, Milicz, Wołów, Głogów, Żary, Żagań. Their arrangement bears witness to the old boundary between the historical territories of Silesia and Greater Poland. The whole area of Lower Silesia bears noticeable traces of multigenerational activities of the various ethnic groups who,.in a long historical perspective, created the cultural landscape of the region together. The variety of these traces and witnesses as well as their coexistence in the present form a structure of many layers. Therefore, the cultural landscape of Lower Silesia resembles a palimpsest, whose subsequent cultural layers require

${ }^{6}$ The understanding of cultural landscape differs according to the area of research. The geographers stress the landscape aspect in the context of the geographical configuration of the terrain and the relations between human economic activities and the natural environment. Whereas culture scientists and historians define the cultural landscape as a historical and social space where the signs of human presence and activities can be seen on many layers. Cf. R. Traba, "Rozważania o magii miejsca i mitologizacji krajobrazu w Prusach Wschodnich" [Deliberation on the magic of a place and mitologisation of landscape in East Prussia], Borussia 2001, No. 24/25, p.40-66. 
comprehensive perception and thorough application of an interpretative strategy, i.e., the constant presence of the broad historical and cultural context.

The cultural landscape of Lower Silesia is thus filled with the witnesses of contacts its subsequent rulers had with neighbouring countries. They take the form of permanent influences in religious architecture (the High Czech Gothic style of the cathedral in Nysa, the Baroque style from the times of the Habsburg monarchy) yet do not lack more unique examples, on the scale of Europe, of defensive and military architecture (knights' castles and tower houses, town walls, fortified churches in the Kłodzko Valley, and the Prussian fortresses and garrison in the Sudety). The cultural landscape is further enriched by the diversity of rural architecture (houses of Lusitian, Sudetian, Jizera, Tyrolean, and Norwegian types) and palaces (Italian and French Renaissance, and the projects by F. Schinkel and other German architects in the Valley of Palaces). The time of the most dynamic changes was the 19th Century, when the agricultural and forest landscape was gradually transformed into a more urbanised and industrialised one. The extent and pace of these changes were so large and significant for the region that the elements of the Prussian and German heritage seem to predominate in the present-day cultural landscape of Lower Silesia. Over the second half of the 19th century, new settlements and towns developed, where the traditional weaving industry, based on home work, began to transform into a mechanised textile industry, which is attested to by the remnants of many factory buildings near Dzierżoniów and Bielawa, Mirsk and Pobiedna, Gryfów Śląski and Prudnik. The sites of the mining and iron and steel industries, which also became mechanised and modernised with the inflow of capital, are visible in the landscape of Wałbrzych and Kamienna Góra, Złoty Stok, Stronie Śląskie, and Nowa Ruda. The local ores facilitated the development of the production of glass, porcelain, and porcelite in the factories in Jelenia Góra and Cieplice, in Pieszyce, Bolesławiec, and Szklarska Poręba.

The beginning of the 19th century was the period of increased interest in the climate and recreational values of this land. It marks the beginning of the large-scale exploitation of thermal springs and mineral resources, known and partially exploited already in the 18th century (Lądek). Water cures brought fame to the spa resorts in Sudety, built to resemble the Swiss ones, e.g., in Cieplice near Jelnia Góra, and in Międzygórze, Polanica, and Kudowa in the Kłodzko Valley. The interest in the region grew even more when, in the middle of the 19th century, the elites of Dresden and Berlin started the fashion for romantic places of recreation. Thus, the mountain dells and valleys became also the space of artistic and literary creation. ${ }^{7}$ Following the

${ }^{7}$ M. Stafa, Karkonosze, Wydawnictwo Dolnośląskie, Wrocław 2006, p. 53-86. 
example of the Prussian king, who built his summer residence in Mysłakowice near Kowary, many other aristocratic families either settled there for good or built their residences in the region. The most famous architects and artists of the time were employed in this effort, sparing no means to achieve the desired results. In a short time, magnificent palaces and residences were constructed in the Jelenia Góra Valley, such as in Łomnica, Wojanów, Bobrów, Bukowiec, Karpniki, Miłków, Kowary, Cieplice, and Jelenia Góra, whose example was followed by many other sites spread over the Sudety Foothils, including the most splendid one: the Palace of Princess Marianne of Orange in Kamieniec Ząbkowicki. ${ }^{8}$ Charity activities for the local community also developed at that time, undertaken mainly by the royal family and people from aristocratic circles. Yet another topic associated with the transformation of the Lower Silesian cultural landscape were the investments of the Prussian government made to increase the economic growth, and also tourism, which was seen as the means to prevent the large unemployment in the foothills of Sudety. New jobs were needed for the weavers who lost their livelihoods after the collapse of the traditional weaving industry. The necessary infrastructure was constructed with a great local effort, including most of all a network of regular rail connections between Wrocław and Brzeg, Wałbrzych, Kamienna Góra, Stronie Śląskie, and Kłodzko, connecting the towns and cities of Silesia with mountain valleys. The investments made in the mountain areas resulted not only in laying tracks but also in the construction of several dozen objects of railroad infrastructures, such as railroad bridges and overpasses, and tunnels. In a short time, tourist trails in the mountains were prepared, with a network of chalets and restaurants. In spa towns a typical spa base was prepared (spa houses, promenade parks and halls, and water drinking rooms), as well as boarding houses and restaurants to guarantee the comfort and safety of the visitors both in the summer and winter conditions. Many of these facilities have survived until present, and their architecture, based on stylised Tyrolean or , less often, Norwegian motifs, contributes to the unique climate of the spa and tourism towns of the Sudety.

Discovering traces of the former glory in the natural environment, corresponding to the Romantic ideas, was in the second half of the 19th century closely associated with the German ideology of learning one's own country by hiking, propagated in guides for the German bourgeoisie.

${ }^{8}$ P. Napierała, A. Środek, W Dolinie Pałaców i Ogrodów. Przewodnik [In the Valley of Palaces and Gardens: A guide], Wrocław 2010, p. 11-17; M. Perzyński, “Tyrol u stóp Karkonoszy” [Tyrol at the foot of the Karkonosze Mountains], in idem, Dolnośląskie zamki, dwory i pałace. Przewodnik dla dociekliwych [Lower Silesian castles, mansions, and palaces: A guide for the curious], Wrocław 2012, p. 34-49.

${ }^{9}$ Cf. R. Traba, "Rozważania o magii miejsca i mitologizacji krajobrazu w Prusach Wschodnich" [Deliberation on the magic of a place and mitologisation of landscape in East Prussia], Borussia 2001, No. 24/25, p.44-45. 
The heritage of memory present in the cultural landscape of Lower Silesia is shown in the multitude of space planning forms, of which the most spectacular ones include dams and dikes on the mountand rivers and the system of storage reservoirs on the Nysa, Bóbr, and Kwisa rivers. The channelling of the course of the Oder was associated with the development of the Silesian river ports, which mostly supplied the industry. While the dense network of rail connections served fast communication with Dresden and Berlin, it was mostly related to the exploitation of natural resources in the foothill areas and supplying the industrial and resource processing plants (quarries, ore and coal mines, coking plants, glass and porcelite works, paper and lumber mills, brickyards, factories, and textile mills).

Therefore, the significant changes which took place in the cultural landscape of Lower Silesia over the 19th century were advanced by the multidirectional activities of the Prussian authorities and private capital, initiated first with the aim to militarise the province (the fortresses and army garrisons in Kłodzko, Nysa, Srebrna Góra, Prudnik), then to urbanise and industrialise it (new industrial settlements, road and rail connections). Settlement activities in this area were continued with the support of the authorities, and became intensified in the middle 19th century. Attempts were made to settle and develop the high meadows of Sudety and revive economically the agricultural and forest areas in the Sudety Foothills.

Even such a synthetic description of the activities of the inhabitants of Lower Silesia, which left traces in the cultural landscape, shows the scale of the task. In many cases, the heritage of the memory of Lower Silesia requires the rediscovery and reinterpretation of the items and objects in their old functions. Yet, most of all, it calls for the exploration of the already blurring traces of the presence of former inhabitants and finding the way to commemorate them in the present.

\section{THE PAST IN THE PRESENT - A STUDY OF THE LOWER SILESIAN SITES OF MEMORY}

The examples of cultural heritage selected for analysis are associated with the time seen in the historical studies as the romantic quest for identity discourse, and its subsequent transformation into the German national discourse. I mean here two "rescue operations" initiated by King Frederick William III of Prussia and continued by his successor. Namely, the transfer of the Norwegian Vang stave church to Karpacz and the settlement of Tyrolean Protestants in the vicinity of the king's palace, in Mysłakowice. The intensive pressure on the cultural identity of the region also took the form of top-down socio-economic initiatives of aid and charity towards the local 
populace. Examples of this kind of activity are associated with the presence of Marianne of Orange and the construction of her residence in Kamieniec Ząbkowicki. Its location in the foothills of Sudety contributed to the association between the construction and a broadere idea of agricultural and industrial recovery of this part of Lower Silesia.

In spite of obvious differences, each of the three analysed cases involves a conscious cultural impact on the local population, associated with the activities of the aristocracy of the time, especially women, involved in the assistance for local communities, such as Marianne of Orange and Friderike von Reden.

\section{THE TYROLEAN HERITAGE OF MEMORY IN THE JELENIA GÓRA VALLEY}

Since 1946, Tyroleans no longer live in the Jelenia Góra Valley, where they arrived in 1837 and farmed for more than a hundred years on the land given to them by the Hohenzollern King of Prussia, Frederick William III, in the vicinity of Mysłakowice (Erdmannsdorf).

After World War II, they shared the fate of all Germans forcefully removed from Lower Silesia. Their houses were inhabited by newly arrived settlers. Even though some houses were destroyed and replaced by new buildings, there are still several dozen objects to be seen in Mysłakowice. The majority of them, however, survived in a good condition to become the part of the cultural heritage left by the Tyroleans visible in the cultural landscape. The surviving objects of material culture received their due care thanks to the common efforts of the inhabitants of the Valley of Zillerthal and Mysłakowice. The history of several generations of Tyroleans who, between one exile and another, created a colourful and culturally rich community, their customs, attire, and cuisine are now becoming a matter of interest of school children and a subject of projects in the area of local and regional history.

The house restored in 1998, serving the double function of a Tyrolean restaurant and a museum, has become a site of memory related to the folk culture of the Tyroleans. In the rooms of the restaurant and in the specially adapted attic of the house, numerous personal memoirs have been gathered, images from various family occasions showing genuine folk costumes, and also the pictures of their imagined homeland, showing the valleys of the Alps, and traditional domestic appliances. The collection of this mini-museum also includes dioramas to reconstruct the architectural details of the Tyrolean style.

Thanks to commemorative actions, the history of Tyrolean emigrants, for many years forgotten, also because it was glossed over on purpose, has found its place anew in the regional history. The Tyrolean House (Pol. Dom Tyrolski), opened in 
1998, became the focal point for the present-day memory of the Tyroleans, owing both to the tokens of material culture gathered theree and the heritage of Tyrolean cuisine. The evocation of the heritage of memory and reconstruction of the history of the arrival of Tyroleans and their settling down in Lower Silesia are a peculiar act of memory towards the heritage of the past and are treated by the today inhabitants of the six Tyrolean communes which participated in the migratory action of 1837 as a kind of compensation.

Without acquiring the knowledge on this and other communities inhabiting the area of Lower Silesia, the elements of cultural heritage present in the cultural landscape will remain silent and inert for our contemporaries. Knowing the past as well as knowing the space in its manifold historical layers makes the present-day inhabitants feel more strongly connected with the place founded on the culture of memory. The way the past is being evoked in the Tyrolean House and the interest in the fates of Tyrolean emigrants in the historical projects carried out by the lodal students and teachers attest to the will to create a community of memory of the Tyrolean heritage in Mysłakowice. There is also room in this history for some interest in the post-war fate of the exiles, as the Tyroleans from Zillertal were driven out of their homesteads twice: once in 1836 from Tyrol, and the second time from Mysłakowice in 1946. The latter fact has still to be addressed by the present-day inhabitants of Mysłakowice. The actions taken so far have been primarily aimed at preserving the traces of the Tyrolean heritage of memory from oblivion in collaboration with the current inhabitants of Tyrol. Tyrolean houses are under conservator's care, and the history of the emigrants is taught at the local school as part of the regional history. It is also available to all interested tourists in the renewed Tyrolean House, now a museum and a restaurant.

In the museum, we can learn that the Tyroleans arrived at Lower Silesia as religious emigrants, forced to leave Tyrol in 1837. As protestants living in the Duchy of Salzburg in the Catholic Austria, they did not benefit from the 1782 Edict of Tolerance. The law in force in Austria did not allow them to freely hold services, buy land, or build houses; they were hampered when selling livestock or produce. In that situation of imminent religious unrest, Joseph II issued an edict under which they had either to convert to Catholicism or be banished. More than 400 people decided to leave their homeland and, having loaded their belongings on wagons, set out in August 1837 for Silesia. Tyroleans, clad in their traditional garb, went afoot in four groups, covering over $700 \mathrm{~km}$ in 21 days. Their leader and guide through Salzburg, Moravia, and Bohemia was Johan Fleidl, who had previously obtain from the King of Prussia Frederick William III a permission to settle down near the royal estate in the Jelenia 
Góra Valley. Upon their arrival in Silesia, the king provided them with legal aid and helped with formalities, so that the first Tyrolean house was built in the autumn of 1838 in what is now Mysłakowice. The exiles were offered settlement near Trzebnica and Brzeg, yet they chose Mysłakowice which most resembled their Ziller Valley. In the first year of their stay, they received significant aid from Countess Friederike von Reden from Bukowiec, who was involved in charity towards Protestants. It was through her efforts that they were lodged for the winter in the nearby Kowary, where a special committee took care of finding temporary lodgings in attic rooms for the new arrivals. The countess bought the wool from which women could make stockings, and gave men work at cleaning forest. In spring, they began the construction of their homes. Both farming and residential buildings were constructed following strict architectural rules, thus creating a unique and original style of wooden architecture, now the heritage of memory of the settlers. The construction works in the Erdmannsdorf-Zillerthal settlement started with the so-called "mock house" in a style similar to Tyrolean; it was burned, and in its place a "Tyrolean inn" was constructed (now the Pod Kasztanami Restaurant).

A model Tyrolean farm consisted of a rectangular, single- or two-storey building (called "Streckof") with a ridged roof. The building consisted of a living area, stable, and barn. Some houses also had a ramp around the upper storey of the barn. The living area was built of wooden logs, surrounded by a porch, and had a low sloping roof. The most characteristic feature of Tyrolean houses are wooden balconies supported by richly decorated brackets, with lavishly profiled balustrades. Plant motifs like open tulip flowers and lilies are predominant in balcony decorations. Simpler balustrades are decorated with geometric shapes, consisting of heart, square, star, or trefoil motifs. The bottom of a balustrade is usually a dovetail-cut comb. An inscription was placed on the balcony of the house of the carpenter Johannes Lublasser, saying: "Gott segne den König Friederich Wilhelm III" [God save the King Frederick William III]. The interior of a Tyrolean house was modest, with a masonry stove occupying the centre of the living area. In 1838-1840, 56 Tyrolean houses were built in Mysłakowice and Sosnówka, and the newcomers tried to instil some of their culture in the locals, like yodel and elements of garments. With time, the differences between the people from Mysłakowice and the Tyroleans blurred, there were more and more mixed marriages, as the latter became known as good farmers, breeders, and cheese-makers.

The memory of their presence has been revived about a dozen years ago at the local primary school, located in the old palace of the Prussian king. The obelisk in front of the school, dated 1887, bears the face of the first Mayor J. Fleidl. 
The impulse to protect the heritage of memory came from the vice-mayor of Mayrhofen in Zillerthal, who strove to purchase and restore the old Tyrolean inn. In spite of many formal issues the effort succeeded, and the house has been open since 1998 thanks to Polish, Austrian, and German cooperation. The cooperating communes organize yearly meetings in the village focused on the elements of the heritage of memory of the Tyroleans and their history.

FROM A NATIONAL TO A EUROPEAN HERITAGE OF MEMORY - THE VANG CHURCH IN KARPACZ GÓRNY

The Vang stave church in Karpacz Górny, visited by over 200 thousand people from around the world, is one of the greatest tourist attractions of Karkonosze. It owes its iconic status in Lower Silesia mainly to its precious architecture, rare in this part of Europe. The Vang church is one of the last 30 surviving medieval stave churches, out of more than a thousand built in Norway in 12 th and 13 th centuries..$^{10}$ The surviving sites are of highest cultural heritage value, which was confirmed by UNESCO listing one of them as a World Heritage Site in 1979 (Urnes Stave Church by the Lusterfjorden in Norway).

From the viewpoint of the research into the heritage of memory of Lower Silesia, the exceptional nature of the Vang church is due, first and foremost, to how the history of its transfer into the Karkonosze illustrates the gradual formation of the awareness of cultural heritage under the influence of Romantic ideas. The church owes its survival to the awareness of an elite group of representatives of scientific and artistic circles as well as aristocrats, who were art collectors. While the cultural heritage awareness developed more widely in the late 19th century, it was seen as a part of a political programme, therefore focusing mainly on the heritage which was considered as national. It was only when the protection of cultural heritage became an international cause after World War II that specialised international organisations were formed and separate legal regulations were introduced.

Yet another aspect of research focused on the heritage of the memory related to the Vang church is perceiving the change, taking place now, in how memory heritage is treated in the areas with multicultural landscapes of the past. The new approach involves a wider interest, which is not solely nationally determined, in the idea of protecting the heritage of memory. On the Vang church example one may notice that there is now a deeper understanding of the necessity to take care of the common cultural heritage sites. This kind of heritage leads to a much wider understanding of

${ }^{10}$ A. Rösner, Kościót Wang. Podróż kościoła stupowo-szkieletowego z norweskich fiordów w Karkonosze [Vang church: The journey of a stave church from the fjords of Norway into Karkonosze], Jelenia Góra 2006, p. 30-34. 
the idea of cultural heritage of memory, as it brings together all who feel the need to participate in this heritage. The Vang church is a great example of focusing the heritage of memory of Norwegians, due to their unique architecture, Germans, to whom it is a symbol of cultural activity in the Silesian Karkonosze area, and Poles, who accepted the role of custodians of this memory, for whom it is also where positive relations with the European cultural heritage are built. For all the above, the Vang church is a component which strongly orients them in the past and present cultural space. From the point of view of the visitors to the Vang stave church, the Lutheran parish in Karpacz and its pastor Edwin Pech (since 1990) not only succeeded in making it a space which commemorates the Vang church as a tourist-friendly place but also care to stress various aspects of memory heritage related to it. The Vang church still fulfills its religious function, which provides additional opportunities to revive the heritage of memory during the meetings of Lutheran communities from Poland, the Czech Republic, Germany, and Norway. Special attention shoudl be given to the contact with the Norwegian Lutheran parish of Vang, whose representatives came to Karpacz in 1992 to celebrate the 150th anniversary of the church's re-erection in the Karkonosze."

Interpreting the history of the transfer of the Vang church from Norway to Karpacz as an example of the early stage in the formation of a conscious approach to the heritage of memory requires an argument in the form of the historical perspective of this unusual translocation. While its arrival in Karpacz in spring 1842, it followed a long battle by Christian Dahl (1788-1857) to save the site. The aim was to preserve it in its original cultural environment, which was also the aim of one Vang inhabitant. When it proved impossible due to the lack of funds, Dahl sought unsuccessfully to keep the church in Norway. The way to save the church, which was dismantled and auctioned because it did not meet the needs of its parish at the time any more, was to find the means to buy the wood and move it to a new place. Such was the fate of the majority of old Norwegian churches in 17th-19th centuries, as they were not aware of irrevocably losing their cultural heritage as a non-renewable value. Such awareness did not arise before the late 19th century. The first to take notice of the issue of protection of wooden churches were the already mentioned Ch. Dahl from Norway, a painter and academy professor educated in Dresden, and his pupil, landscape painer and architect Franz W. Schiertz (1815-1887). During his three study journeys to Norway, as attested by his notes, Dahl saw in old churches the incalculable value of the disappearing medieval wooden architecture. ${ }^{12}$ Whereas Schiertz described the

${ }^{11}$ J. Moniatowicz, E. Pech, Wang, Karpacz 1993, p. 95-96.

${ }^{12}$ A. Rösner, Kościót Wang. Podróż kościoła stupowo-szkieletowego z norweskich fiordów w Karkonosze [Vang church: The journey of a stave church from the fjords of Norway into Karkonosze], Jelenia Góra 2006, p. 38-44. 
construction of these churches and provided its documentation. ${ }^{13}$ Both tried in vain to draw attention to the necessity of protecting this Norwegian cultural heritage. In 1841, Dahl's efforts led to the purchase at an auction of the church from Vang. Dahl placed the bid on behalf of King Frederick William IV of Prussia. At a cost exceeding its price many times, the church was transported to Berlin, where it was meant to adorn the Pfaueninsel (Peacock Island). The wooden structure of the church, dismantled and packed in crates, was shipped from Bergen to Stettin by sea, then by river to Berlin. The crates were being stored at the Old Museum warehouses in Berlin, when the king changed his mind and, entreated by baroness Friderike von Reden, donated it to serve the needs of the Luterans in the Karpacz Górny (Brückenberg) area. In spring 1842, the transport to the Karkonosze began, first to Sosnówka, then to the slopes of the Black Mountain (Černá hora). The foundation stone was placed in August 1842 with the king's participation, and in July 1844 the Vang mountain church, saved thanks to the Prussian king's interest in Scandinavian architecture, was consecrated. In 1856, the king founded a marble monument bearing the relief of Friderike von Reden to honour her contributions to the local community and Lutheran parish. It is located in the niche of the western scarp by tye Vang church, in line with its memorative role.

From the beginning the Vang church was perceived as a precious site of early medieval architecture, and so its characteristic silhouette was often depicted on postcards. ${ }^{14}$ The church and its furnishings are among the most valuable wooden buildings in the whole Europe. The 12th-century carved portals and column capitals are of particular value. The missing carved parts and the oaken cross were made by Jacob Janowitz in the mid-19th century. The role of consequent pastors in commemorating the church's history was invaluable. Histories of the church was compiled in 1848, 1896, 1924, 1993..$^{15}$ Based on illustrated sources, they told about its Scandinavian roots, explained its construction and the symbolism of sculptures, and so rooted the Vang church in the consciousness of believers and tourists.

After World War II, the religious function of the church was broadened into civic activities. It was initially treated as a local curiosity and shown to the tourists visiting the Karkonosze Mountains. Since the 1990s, howver the Vang church has been not just the centre of the Lutheran parish activities, it has also been receiving

${ }^{13}$ A. Rösner, Kościót Wang. Podróż kościoła stupowo-szkieletowego z norweskich fiordów w Karkonosze [Vang church: The journey of a stave church from the fjords of Norway into Karkonosze], Jelenia Góra 2006, p. 66-67.

${ }^{14}$ Cf. J. Ratajski, Karkonosze na dawnych widokówkach [Karkonosze on vintage postcards], Jelenia Góra 2015, p. 153-156. The book comprises 231 old postcards made by Oskar Keil's lithographic establishment at the turn of the 20th century, furnished with a historical commentary.

${ }^{15}$ A. Rösner, Kościót Wang. Podróż kościoła stupowo-szkieletowego z norweskich fiordów w Karkonosze [Vang church: The journey of a stave church from the fjords of Norway into Karkonosze], Jelenia Góra 2006, p. 93-94. 
constant conservation care and protection. It has sereved various cultural functions and been open to the tourists since it was made an interesting site on the "Via sacra" tourist trail connecting historical monuments in Saxony and in both Czech and Polish Karkonosze. Choral and classical music concerts are being regularly held in the church. An ecumenical cultural centre has been active by the parish since 1990, and the common choir of the Lutheran and Catholic parishes. The parish has initiated many activities to integrate the inhabitants of Karpacz, such as constructing a tourist path around the Vang church. The diaconate organises social activities and health prophylaxis, as well as medical assistance for the local community (first aid, cardiological diagnostics, medical courses for Lutheran youth from Poland, Germany, and the Czech Republic). The parish has extensive contacts with Luteran parishes on the other side of the Karkonosze (Pec, Vrchlabi). The Luteran cemetary by the church, where pastors and mountain chalet owners were buried of old, has recently become an informal cemetery for outstanding people of culture from Silesia, who were $\mathrm{Lu}$ therans. The founer of pantomime Henryk Tomaszewski and poet Tadeusz Różewicz are buried there. The Vang parish carries out wide-ranging publishing, research, and artistic activities, also recently supported with EU means received in the framework of various projects. Vang is a church, a monument, and a meeting place for people from many European countries. It is one of very few sites in Lower Silesia which functions according to the idea of protecting the heritage of memory and is involved in organising cultural life.

\section{HERITAGE OF MEMORY ASSOCIATED WITH MARIANNE OF ORANGE}

In the case of the heritage of memory related to Marianne of Orange, various local initiatives to commemorate her can only be seen in the recent years. It can be considered a cultural phenomenon of the Kłodzko Valley and Kamieniec Ząbkowicki that the memory of Marianne as the "Good Lady" survived in many towns and villages of Lower Silesia. Marianne of Orange is not always associated with particular examples of her broad socio-economic activities. As the proprietor of the south-western part of the Kłodzko Valley, she contributed to the civilisational development of the area. She founded the crystal glass factory in Stronie, colour marble quarry in Kletno, the network of roads in the Śnieżnik Mountains, and the public road connecting the areas of Złoty Stok, Lądek Zdrój, Stronie Śląskie, and further towards Moravia. Marianne of Orange had the oldest chalet in the Sudetes built under Śnieżnik (1871), named after her, and successfully promoted Międzygórze as an attractive tourist destination. Her activities opened the wildest and least accessible part of the Kłodzko Valley. Each of her numerous economic and construction initiatives created opportunities 
to earn money for local inhabitants. She introduced new methods of farming, animal husbandry, and cheese production based on the Swiss ones to contribute to the development of farming and improve the living condition of the local populace. Her charitable activities (construction of hospitals and orphanages, aiding lone women) took the form of comprehensive social care rather than alms. It was most likely due to this humane trait of hers that Marianne of Orange quickly grew into the cultural landscape of the Kłodzko Land and the areas near Kamieniec Ząbkowicki, where she arrived in 1838, having inherited from her mother the Kamnitz estate after the Cistercian abbey was secularised. ${ }^{16}$ While the palace (castle) in Kamieniec Ząbkowicki is the most spectacular cultural heirloom associated with Marianne, the heritage of her memory seems to lie rather with the results of her socio-economic activities, as she realised daring plans to organise the area, just like its former owners, the Cistercians. She was remembered as an outstanding and impressive protector of the people living in her land. Having divorced Frederick Hohenzollern, she completed the construction of the palace in Kamieniec Ząbkowicki, then one of the largest Romantic castles in Europe. She gave the palace, designed by K.F. Schinkel and built in 1837-1863, to her son Albrecht. Its official opening took place in 1872. The garden and parts of the palace were seasonally open to visitors in the 1920s. The palace with its furnishings survived World War II and only succumbed to devastation in the post-war era.

In the recent years, the collaboration between Polish and Czech border communes, the Marianne of Orange Cross-border Trail was marked on the route from Kamieniec Ząbkowicki, through Międzygórze, Śnieżnik, Stronie Śląskie, Lądek Zdrój, Javornik, and Bila Voda. ${ }^{17}$ Each of the above municipalities holds either a specific part of Marianne of Orange's historical witness or an example of her activities. Taking advantage of the uniformly positive image of Marianne of Orange in the region, local authorities prepared a diversified tourist offer. Materials regarding the path of the qualified trail were prepared, as well as a the set of tourist badges in three classes. Yet the activities of communes in commemorating Marianne of Orange are diverse and not limited to the idea of the trail. The Kamieniec Ząbkowicki commune is the most involved in the project due to having taken over the legal and conservation care of the palace, now treated both as a centrepiece of the memory of Marianne of Orange and a tourist attraction of the greatest development potential. Thanks to the efforts of the local authorities, the palace is now under comprehensive conservation care, which

${ }^{16}$ M. Gaworski, Pałac w Kamieńcu Ząbkowickim [The palace in Kamieniec Ząbkowicki], Strzelce Opolskie 2009 , p. 37.

${ }_{17}$ Marianna Orańska a Ziemia Kłodzka. Materiały z sympozjum zorganizowanego przez Muzeum Ziemi Kłodzkiej w Kłodzku 17 czerwca 2010 r. [Princess Marianne of Orange and the Klodzko Land: The proceedisngs of the symposium held by the Museum of the Klodzko Land on 17 June 2010], Kłodzko 2010, p. 77. 
makes possible the reconstruction of the site, devastated after the war, which could not be done by individual due to the scope of works and necessary funds. The works carried out now aim at commemorating the life and activities of Marianne of Orange through permanent and temporary exhibitions, photographs and films showing the old palace interiors and gardens, and guided tours of the renovated rooms, courtyards, and gardens of the palace. With tourists in mind, the local authorities prepared a historical guide and plan of the site. There are also thematic websites.

Another site very strongly associated with Marianne of Orange, with a high potential to affect tourists like Kamieniec, is the well-known mountain spa in Międzygórze, constructed and promoted by Princess Marianne, which preserves components of the Tyrolean and Scandinavian wooden architecture. Both the municipality and its surrounding villages, which belonged to Marianne of Orange in the 19th century, try to relate to her person and activities. The local chapter of the Polish Tourist and Sightseeing Society (Pol. Polskie Towarzystwo Turystyczno Krajoznawcze - PTTK) organises raids with variable routes, themed on the heritage of Marianne's memory.

The astonishing lack of interest in the subject of Marianne of Orange on the part of official historiography until the 1990s attested to the problems in understanding the aims and values of protecting cultural heritage where it is not identified with the heritage perceived as one's own, where it is not the same as national culture. However, this gap is beginning to be filled by local and regional publications.

\section{THE TRANSFORMATION OF CULTURAL HERITAGE INTO THE HERITAGE OF MEMORY}

The presentation of sites and related communities was shown from two intersecting perspectives, historical and cultural, relevant to the research assumptions of the project. Namely, first came the historical perspective, focused on the point in time where the Prussian cultural heritage emerged in Lower Silesia and recording how its components grew into the local cultural landscape, which process took the most dynamic form in the 19th century. The other perspective enabled approaching this heritage from the direction of its present-day importance to the local community, which settled these lands after the war. For the local communities, this cultural heritage has only recently and gradually been becoming a component of their long-term memory, part of the multicultural heritage of Lower Silesia over the centuries.

The conclusions from observation I adduce are limited to the above examples of heritage of memory and I do not intend them as statements of more general nature. Examining other cases might allow the formulation of more meaningful generalisa- 
tions. Already at this stage of research, however, it is possible to differentiate between several historically conditioned developmental stages of the complex functioning of the cultural heritage and heritage of memory of Lower Silesia.

An important point of origin triggering the post-war events and precipitating even more, was the displacement of the German populace under international agreements and subsequent resettlement of the area with the Polish populace removed from the former Eastern reaches, which until 1939 were part of Poland. In social terms, these decisions led to a forced emigration process on both sides, associated with the loss, to both resettled population groups, of not just large parts of their belongings but, first and foremost, their sense of belonging. The result of breaking the cultural continuity in the area and the first stage of the process was the non-identification with the foreign cultural heritage, leading to its conscious or unconscious destruction or purely instrumental use. The lack of legal regulations to guarantee the ownership of land and occupied real estate led to a state of uncertainty and temporariness among the settlers, skilfully fuelled by the Communists' ideological speeches on the one hand, and the disturbing declarations of Revisionists, pronounced in the Cold-War conditions. This state of affairs contributed to the ongoing devastation of cultural heritage, part of which in rural areas remained unsettled in the initial post-war period, and poorly developed as well.

Wherever the heritage of memory was culturally foreign, it was systematically appropriated or destroyed by the newcomers who had lost their own place on the earth. Also, the foreignness of this heritage often involved the complete lack of information about its former owners. Therefore, in a simplified and often erroneous association, movable and immovable property was schematically and anonymously tied to an impersonal enemy. Depriving sites of their subjective reference to specific people resulted in a void, filled with fear that the dangers may return. The behaviours of the settlers were closely tied to their "living history", i.e., with what was still fresh in the collective memory and could be magnified by individual memories, in particular the experience of one's place to live and belongings. Since this state continued for many years, which was the intended result of the Cold-War situation on both sides of the new border, it increased the sense of uncertainty and temporariness of the Polish settlement in Lower Silesia. The negative attitude towards the previous inhabitants and the heritage they left resulted in neglect, which continued in many places until the 1980s. Only on rare occasions this took the form of conscious, or even planned destruction of the sites treated in the period of post-war rebuilding of the country as an easily accessible pool of high-quality construction materials, as was the case of 
Marianne of Orange's palace in Kamieniec Ząbkowicki. The lack of clear legal regulations of the ownership of land and estate in the area made the situation even worse.

It took many years before the next generation gained the sense from belonging that comes from one's own permanent place in the cultural landscape and triggers the identification process. Starting the process of identification with cultural landscape requires permanent focal points, such as places of religious worship, persons, and phenomena one can identify with. Before foreign cultural heritage becomes heritage of memory, it is necessary to establish rituals, of which the every-day care of the site is the most edifying one. Whereas introducing cyclical events into the cultural landscape make the historical time run again.

The post-war Polish community inhabiting the area of Lower Silesia underwent a transformation of mentality and consciousness over four generations. It made its way from mutual aversion and enmity, through the destruction of property perceived as foreign or lack of interest and care of the heritage seen as foreign, to the stage of its protection (after 1990), followed by the stage where attempts were made to commemorate the cultural heritage (especially after 2004). Only when a heritage is culturally domesticated and cared for by its users it slowly loses its foreign traits and becomes a consciously protected common inheritance. The number of renovated relics of the past in Lower Silesia increases substantially each year. Thay shine again thanks to the work of conservators and efforts of members of local communities and foundations. The revitalisation of historical objects and sites more and more often involves the restoration of a heritage of memory with the participation of a local community or patronage of local authorities. In the recent years, also the descendants of those who were forced to leave their homeland following the war become involved in the restoration of the memory heritage, as illustrated by the German community coming from Otmuchów.

Conversely, this heritage, which is a nationally and culturally foreign component, was systematically appropriated or destroyed by the newcomers, who had lost their own. The foreignness of this heritage did not remind them of the previous inhabitants and owners as much as it was associated with Germans. It was closely related to the war experiences, still fresh in the collective memory, additionally strengthened by individual recollections of the loss of a place to live of one's own and belongings. Since this state continued for many years, which was the intended result of the Cold-War situation on both sides of the new border, it increased the sense of uncertainty and temporariness of the Polish settlement in Lower Silesia. The negative attitude to the previous inhabitants and the heritage they left, present from the beginning, deepened with passing years. It was not only the result of neglect, continuing until the 1980s, 
but in many cases also conscious, planned destruction of the objects, which during the post-war reconstruction of the country was treated as an easily accessible pool of high-quality construction materials. The lack of clear legal regulations of the ownership of land and estate in the area made the situation even worse.

\section{CONCLUSION}

What might be considered crucial in the context of the conducted research is the attempt to find the answer to the question what kind of argumentation regarding the sites of memory of the Lower Silesian cultural heritage is currently predominant. Each of the discussed cased was presented not fragmentarily but rather in a slightly broader historical context. In the case of Lower Silesia, the broad time spectrum made it possible to take into account the palimpsest nature of the cultural heritage and heritage of memory. The post-war period, which is of interest to us, initially brought silence about the heritage of memory, which was related to the strategy of conscious supression and eradication of the memory of cultural heritage: as was the fate of Marianne of Orange's palace in Kamieniec Ząbkowicki. Later, the consent to the devastation of some of the objects was an intentional and consequently enforced policy of oblivion regarding the Lower Silesian heritage.

The study of object examples was accompanied by a reflection which took into account the historical variability of the conditions in which "inheriting the memory" took place. First, the fates of the multidimensional cultural heritage were drastically complicated, mostly due to the post-war political and ideological conditions. Moreover, the mass relocations of the local German population, carried out in the spring and summer of 1946, led to the breaking of cultural continuity in a large part of Lower Silesia. In such tangled circumstances, the Silesian towns and villages were settled anew by an ethnically non-homogeneous, yet mostly Polish, population. The new settlers arrived in the deserted Lower Silesian land as forced deportees from the eastern reaches of the pre-war Polish states and the areas of Greater Poland and Mazovia. Due to the double breakage of the cultural continuity of both the former and the new inhabitants of Lower Silesia, their individual memories were locked for many year as a constant part of a personal trauma. This state may be called a permanent mutilation of memory due to the loss of one's own place to live and the sense of cultural identity associated with it both in the individual and collective dimension, as well as the complete lack of permanent reference points in the cultural space, necessary for the sense of identity.

The people from such afflicted generations suffered their personal tragedies for many years on both sides of the new border, in the atmosphere of mutual disdain and 
hatred, intentionally fuelled with ideological means. The sense of uncertainty was used in a political struggle. What is more, in order to promote political and social integration of these areas, the Communists introduced the mythical concept of Recovered Territories, which seemed useful as a historical argument but proved dangerous for some of the Silesian heritage. For the topos of a return led to the projection of the modern idea of a nation to the medieval times and presaged the re-Polonisation of Silesia. Simultaneously, there emerged a negative attitude towards the "foreign", or German, cultural heritage, which dominated in the cultural landscape of Lower Silesia.

The changed political context after the western borders of Poland were recognised by West Germany (1970) and even more strongly after the German reunification (1990) and Polish accession to the EU (2004) strongly influenced the political relations and cotributed to the improved mutual relations in the contacts between both societies. The disappearance of old prejudices and attitudes, itself part of the historical process involving subsequent generations, leads to a different approach to the heritage of memory.

From the viewpoint of the formal responsibility for the cultural heritage, under Polish and international law, the conservation supervision and legal protection of the cultural heritage of the region is performed by specialised agencies of the Polish state as well as by the direct local owners such as local authorities and individuals. Following the transformations of 1989, all the above entities recognise the protection of cultural heritage, understood as a whole, as a significant value, thus including the heritage which is not national. As symbolic heritage, the heritage of memory is inseparably fused with the cultural landscape of the region.

The significance of the heritage understood so becomes significant in the context of building a modern cultural identity, defined and perceived in many aspects. Within the limits of old historical regions, the EU legislation promotes the return to treating the heritage of memory as cross-border and culturally coherent. The heritage of memory spread over areas which had once been culturally and politically coherent becomes the challenge of today and is considered as catalysing a new quality of contacts in cross-border areas. The local and regional historical perspective (e.g., the Lusatia subregion, the regions of Kłodzko and Nysa) enables the perception of old social, economic, cultural, and religious connections in cross-border areas.

The thinking in a broader cultural perspective is increasingly often associated by a narrow perception of heritage of memory as just local or just national. Changes in the approach to the issue of historical heritage as a cultural heritage of memory have been a strong tendency in the last decade. The care of the heritage of memory is 
seen as the task worthy of the interest of local authorities and other organised communities of the inhabitants of a region. The strongly political question of identifying the old Prussian heritage with the German, and the German one with the enemy, is no longer relevant in the majority of Lower Silesia. The appreciation of the Lower Silesian heritage of memory as precious and important Europe-wide led to accelerate the process of its protection and care.

Each of the examples discussed above showed the early formation, as it took place in the 19th century, of the awareness of cultural heritage as well as the various forms in which it is commemorated. This heritage, in spite of the political and social cataclysm which led to the breaking of cultural continuity in the majority of the Lower Silesian area after World War II, survived in the rare cases where at least vestigial forms of it were still being practiced in the culture. I have the following facts in mind: first, the continuity of the religious Lutheran community in the Vang church, which preserved one of the old functions of the site; second, the cultural distinctiveness of the Norwegian and Tyrolean architectures, which differed from the rest of the cultural environment and did so did not cause negative connotations, often being used for the purposes of representation and tourism; third, a strong need for unequivocally positive components of a local tradition, which allowed the cult of Princess Marianne of Orange to survive. Her respectable economic activities and aid for the local community, coupled with her royal origin and tragic personal history, survived in local stories and were partly transformed into a myth. Such a suspension of Marianne of Orange in the mythical time-space of a legend facilitated her adaptation by the new inhabitants, who did not personally experienced her activities and yet sustained her presence in the local tradition. The Kłodzko Valley played a crucial role in this case, as it is filled with old sites carrying the memory of her as the person of great value for the region. The selected examples show that the cultural landscape, preserving the elements of tradition, can serve the role of fusing the old with the new, even in such dificult cases as the breakage of cultural tradition diagnosed in Lower Silesia. Finding these scarcely present and thin threads of cultural warp enables the co-creation of a new layer of memory in the palimpsest-like structure of the cultural heritage even after many years. 
Błogosławiony kraj? Szkice o historii i pamięci Dolnego Śląska, red. D. Mrgiela, K. Ruchniewicz, Wrocław 2011.

Dolny Ślask. Monografia historyczna, red. W. Wrzesiński, Wrocław 2009.

Gaworski M., Pałac w Kamieńcu Ząbkowickim, Strzelce Opolskie 2009.

Marianna Orańska a Ziemia Kłodzka. Materiały z sympozjum zorganizowanego przez Muzeum Ziemi Kłodzkiej, Kłodzko 2010.

Moniatowicz J., E. Pech, Wang, Karpacz 1993.

Napierała P., A. Środek, W Dolinie Pałaców i Ogrodów. Przewodnik, Wrocław 2010.

Pamięć zbiorowa i kulturowa. Wspótczesna perspektywa niemiecka wobec pamięci, red. M. Saryusz-Wolska, Kraków 2009.

Perzyński M. Dolnoślaskie zamki, dwory i pałace. Przewodnik dla dociekliwych, Wrocław 2012.

Ratajski J., Karkonosze na dawnych widokówkach, Jelenia Góra 2015.

Regionalizm polski u progu XXI wieku, red. S. Bednarek, Wrocław 1994.

Rösner A., Kościót Wang. Podróż kościoła stupowo-szkieletowego z norweskich fiordów w Karkonosze, Jelenia Góra 2006.

Stafa M., Karkonosze, Wrocław 2006, s. 53-86.

Szacka B., Czas przeszły, pamięć i mit, Warszawa 2006;

Śląsk. Rzeczywistości wyobrażone, red. W. Kunicki, N. K. Żarski, Poznań 2009.

Traba R., Rozważania o magii miejsca i mitologizacji krajobrazu w Prusach Wschodnich, Borussia 2001, nr 24/25, s. 40-66. 